\title{
Personality Attributes of Successful Franchisees in the Fast Foods Sector in South Africa
}

\author{
B von H Kasselmann \\ Interaction Dynamics, Pretoria
}

Johannes $\mathbf{J}$ de Beer and Leopold $\mathbf{P}$ Vermeulen

Department of Human Resources Management, University of Pretoria

\section{ABSTRACT}

The aim of the study was to identify the personality traits, emotive responses and attitudinal orientation of franchisees. Cattell's 16 Personality Factor Questionnaire, the Personal Profile Analysis of Thomas Intemational and Boshoff's Entrepreneurial Attitude Questionnaire were used. Measurements were obtained in respect of a sample of 80 restaurants belonging to a fast foods franchise. A stepwise discriminant analysis identified statistically significant differences between successful and unsuccessful groups in respect of five factors. Successful franchisees were emotionally more stable and sober-minded, exhibited a higher degree of shrewdness, displayed higher self-esteem, and were more compliant. The Jack-Knife Classification was used in devising a classification table to compare the observed and predicted success rates of franchisees. The study found that the identified five factors could be used to predict the potential success rate of franchisees.

JEL M13

\section{INTRODUCTION}

Recently, the South African government has emphasised the need to develop the small business sector in general. The business format of franchising in particular offers a proven avenue for creating employment, responsibility and wealth. The worldwide phenomena of urbanisation, rising disposable income and expanding consumer markets, coupled with changing work patterns and an increasing number of people looking toward self-employment have provided a sound foundation for the rapid growth of franchising over the last few decades (Macmillan, 1996). Today the business concept of franchising is well established and has been tried and tested in virtually every domain of business.

In South Africa the annual growth in franchise systems since 1994 is 32.5 per cent (Franchise Directions, 1999). Franchise systems span 12 business 
categories, The largest of these are retail (15.9 per cent), fast foods (15.1 per cent), education and training (11.5 per cent), automotive products (11.1 per cent) and restaurants (10.6 per cent). The retail turnover of franchise systems has shown an annual average growth of 54.6 per cent since 1994. The total retail turnover in the franchise sector in 1998 was R39, 969 billion and retail franchises provided employment to 266104 people. Retail turnover through franchising contributed 11.5 per cent to annual private consumption for 1998 , constituting an increase of 85 per cent since 1995. A total of 147 franchisors out of 358 franchise systems in operation ( 41 per cent) responded to the survey. Judging by these findings, franchising can help South Africa to meet the daunting challenges of skills development, job creation and wealth creation.

A business franchise is generally defined as the entitlement of a franchisee by a franchisor to trade under the trademark of the franchise and to make use of a package comprising all the elements necessary to establish a business. This involves the development by the franchisor of a blueprint for conducting the business, which eliminates as far as possible the risks inherent in opening a new business by setting out in detail exactly how the business should be run. The pre-established format coupled with the backing of the franchisor's organisation enables a person who has never before owned or operated a business to start a business. The franchise agreement also establishes the format for a comprehensive and continuing relationship in which the initial franchise concept as well as participating franchisees are continually developed (Mendelsohn, 1994).

The prerequisite for establishing a franchise is that a business must possess definable "know-how" coupled with a distinct way of doing things, which distinguishes it from other businesses (Abell, 1992). Setting up a franchise involves five distinct stages:

- The development of a successful business concept that can be replicated elsewhere.

- The successful implementation of a pilot scheme.

- The production of a business operations manual, franchise agreement and marketing prospectus.

- The marketing of the franchise through appropriate channels.

- The establishment of an appropriate franchise selection system together with arrangements for training of new franchisees, including the provision of pre-opening assistance and continued support.

It is generally easier to start a second, third or fourth venture than it is to start a first one, as entrepreneurial expertise increases with time and experience (Hisrich \& Brush, 1986). The franchisor not only provides this entrepreneurial 
expertise but also acts as a role model and mentor, which is one of the most important factors in encouraging entrepreneurship (Hisrich, 1990). This supportive role is particularly crucial during the start-up phase, when the franchisor provides information, advice and guidance on such matters as organisational structure, the management control system, the financial resources needed, the location of the business (site), market segmentation and marketing.

In view of the relative security that the franchise format offers, it is debatable whether franchisees are required to display entrepreneurial behaviours to any great degree. In fact, they appear to fulfil a distinctly managerial type role in the franchise operation. The roles of entrepreneur and manager suggest different characteristics, competencies and skills. Whereas entrepreneurs are expected to be skilled in envisioning possibilities, managers are usually thought of as exercising rational thinking and detail-oriented administrative skills. Franchisees appear to be most similar to intrapreneurs who develop profitable businesses within the confines of an existing business entity (Pinchot, 1985).

Intrapreneurship emerged as a hybrid form of entrepreneurship, due in part to the high risks and costs involved in entrepreneurship. Intrapreneurs are corporate entrepreneurs who pursue independent and creative business opportunities under the overall supervision of the corporation, expect their performance to be suitably rewarded, yet are prepared to let the corporation decide on the nature and size of the reward (Pinchot, 1985). Intrapreneurs share the same entrepreneurial spirit as entrepreneurs in terms of taking risks to achieve goals. However, to a large degree, they also behave like managers, because they follow corporate policies and procedures in the process of achieving goals. Intrapreneurs appear to fall somewhere between the total involvement of entrepreneurs in all stages of the business venture, and the delegated responsibility of managers who act within an established framework. This is similar to the partnership between franchisor and franchisee in which both have a financial stake in the business and take mutual responsibility for maintaining operational standards and achieving financial goals. The main perceived differences/similarities between entrepreneurs, intrapreneurs, franchisees and managers are set out in Table 1.

It appears that franchisees, much like intrapreneurs, exercise a unique blend of entrepreneurial and managerial characteristics by exposing themselves to a moderate degree of risk within a proven and established business framework. Franchisees are, on the one hand, like entrepreneurs (and less like intrapreneurs), because they risk their own financial security by investing money in a business. On the other hand, they are like managers (and less like intrapreneurs) because they minimise experimentation by managing the business strictly in accordance with the franchise agreement. In essence, 
franchising is a partnership. Franchisors charge a fixed fee upfront to establish new franchise outlets, but the major share of their income is derived from royalties based on turnover. This makes franchisees the major asset of a franchise (Mendelsohn, 1994; Franchize Directions, 1999).

Harris (1993) suggests that the most difficult aspect of franchising is getting the recruitment practice right. This was confirmed by a survey conducted among exhibitors at the National Franchise Exhibition held in Birmingham during 1994, which indicated that the majority of franchisors considered targeting the correct audience for recruitment purposes as the biggest problem area in establishing a franchise (Macmillan, 1996). More than 60 per cent of all franchisors in the survey converted 5 per cent or less of initial enquiries for information into franchise sales. At the same time, as many as 72 per cent of respondents estimated the recruitment cost per franchisee to be between R30 000 to R70 000 - expressed in 1993 Rand value terms.

Table 1 Comparison of entrepreneurs, intrapreneurs, franchisees and managers

\begin{tabular}{|c|c|c|c|c|}
\hline Trait & Entrepreneurs & Intrapreneurs & Franchisees & Managers \\
\hline $\begin{array}{l}\text { Primary } \\
\text { motives }\end{array}$ & $\begin{array}{l}\text { Independence, } \\
\text { creativity and } \\
\text { money }\end{array}$ & $\begin{array}{l}\text { Interdependence, } \\
\text { advancement and } \\
\text { corporate rewards }\end{array}$ & $\begin{array}{l}\text { Interdependence, } \\
\text { self-employment } \\
\text { and money }\end{array}$ & $\begin{array}{l}\text { Promotion and } \\
\text { corporate } \\
\text { rewards }\end{array}$ \\
\hline $\begin{array}{l}\text { Risk } \\
\text { taking }\end{array}$ & Moderate to high & Moderate & Limit risk & Control risk \\
\hline $\begin{array}{l}\text { Failures } \\
\text { and } \\
\text { mistakes }\end{array}$ & $\begin{array}{l}\text { Deal with } \\
\text { failures and } \\
\text { mistakes }\end{array}$ & $\begin{array}{l}\text { Hide risky projects } \\
\text { from view till ready }\end{array}$ & $\begin{array}{l}\text { Minimise } \\
\text { chances of failure } \\
\text { and mistakes }\end{array}$ & $\begin{array}{l}\text { Try to avoid } \\
\text { failures and } \\
\text { mistakes }\end{array}$ \\
\hline Activity & $\begin{array}{l}\text { Direct } \\
\text { involvement in } \\
\text { all aspects of the } \\
\text { business }\end{array}$ & $\begin{array}{l}\text { Direct involvement } \\
\text { more than } \\
\text { delegation }\end{array}$ & $\begin{array}{l}\text { Direct involve- } \\
\text { ment with some } \\
\text { delegation }\end{array}$ & $\begin{array}{l}\text { Delegate and } \\
\text { supervise, more } \\
\text { than direct } \\
\text { involvement }\end{array}$ \\
\hline $\begin{array}{l}\text { Deci- } \\
\text { sions }\end{array}$ & $\begin{array}{l}\text { Follow own } \\
\text { vision }\end{array}$ & $\begin{array}{l}\text { Try to get others to } \\
\text { help achieve own } \\
\text { vision }\end{array}$ & $\begin{array}{l}\text { Support the } \\
\text { vision of the } \\
\text { franchisor }\end{array}$ & $\begin{array}{l}\text { Usually agree } \\
\text { with senior } \\
\text { management }\end{array}$ \\
\hline $\begin{array}{l}\text { Who } \\
\text { serves }\end{array}$ & $\begin{array}{l}\text { Self and } \\
\text { customers }\end{array}$ & $\begin{array}{l}\text { Self, customers and } \\
\text { sponsors }\end{array}$ & $\begin{array}{l}\text { Self, customers } \\
\text { and franchisor }\end{array}$ & The corporation \\
\hline $\begin{array}{l}\text { Time } \\
\text { orien- } \\
\text { tation }\end{array}$ & $\begin{array}{l}\text { Long-term focus } \\
\text { on survival, } \\
\text { growth, sales and } \\
\text { profits }\end{array}$ & $\begin{array}{l}\text { Depend on urgency } \\
\text { of self-imposed and } \\
\text { corporate time- } \\
\text { tables }\end{array}$ & $\begin{array}{l}\text { Long-term focus } \\
\text { on profits and } \\
\text { return on } \\
\text { investment }\end{array}$ & $\begin{array}{l}\text { Short-term } \\
\text { focus on } \\
\text { achieving } \\
\text { targets and } \\
\text { budgets }\end{array}$ \\
\hline
\end{tabular}

This table is an extensively modified version of a table by Hisrich $(1990: 218)$ 
Stanworth (1995) argues that conversion rates for becoming a successful franchisee are low, because, while many people desire self-employment, few people really understand what is involved. To most people the main attraction seems to be the grand notion of "doing their own thing with no one looking over their shoulders". The benefit of previous experience of self-employment is that it creates a strong awareness among potential franchisees of the need for a proven business system, which offers more "security", "access to a known tradename" and "business back-up". However, the majority of franchisors believe that the personal qualities of franchisees are very different from the personal qualities of fully self-employed business people.

Stanworth (1995) asserts that the selection of franchisees is further complicated by a number of additional factors:

- Some franchisors feel that their experience naturally equips them to identify good or bad potential franchisees on an instinctive "gut feel" basis.

- Most developing franchises have only a few staff members who undertake a multitude of tasks and few of them possess expertise in the field of personnel selection.

- Quite often, franchisors fall into the trap of looking for people exactly like themselves, when it would be best to select franchisees who complement rather than duplicate their own abilities and weaknesses.

South African franchisors seem to hold essentially the same views on recruitment and selection issues as their intemational counterparts. A survey conducted by Kasselmann (1996) at the South African Franchise Association and among leading franchisors in the fast foods and restaurant categories indicated that very little, if any, research had been conducted in the South African franchise sector to address selection issues. The single most important selection factor appeared to be whether an applicant could obtain guaranteed financing. In fact, applicants were seldom rejected on the basis of biographical, educational or demographic factors. The majority of those surveyed were quick to emphasise the need for more scientific selection methods. Overall, the survey suggested that franchisors were uncertain about how to define the unique blend of entrepreneurial and managerial qualities required of ideal franchisees.

Kasselmann's (1996) survey highlighted the classic conflict in the industry between encouraging franchisees to use their initiative to develop a successful small business, and exercising strict controls over the products sold and methods employed in terms of the franchise agreement. A key question remains which mix of entrepreneurial and managerial characteristics may predispose a person towards becoming an effective franchisee. How can one identify these 
characteristics? There is clearly a need to identify indicators in terms of personal qualities or characteristics which could be used as reliable and valid predictors in the selection process for the development of appropriate competencies in franchisees.

The main aim of the study set out in this article was to identify personality attributes (and an instrument or instruments to measure such attributes) that differentiate between effective and less effective performers among franchisees, according to the performance criteria of a franchise company in the fast foods category.

\section{IDENTIFYING DESIRABLE QUALITIES IN FRANCHISEES AS ENTREPRENEURS}

Recently, Gordon (1999), managing partner of Parker Gordon Associates (a leading South African consulting company in the franchise sector who conducts regular surveys to monitor the development of franchising), indicated that there has been little or no South African research to investigate the relationship between the personal qualities of franchisees and actual work performance in the franchise sector. The little literature that is available does not provide clear and conclusive evidence as to what characteristics are common to franchisees, although there are at least three theoretical and methodological approaches which are generally used to research the characteristics of entrepreneurship (Lau, 1992). First, there is the trait approach, which focuses on the personality theory underlying the notion that there is a form of individual behaviour which can be identified as entrepreneurial or non-entrepreneurial (Brockhaus \& Horwitz, 1986; Gartner, 1988). The second approach uses demographic information such as age, level of education, and work habits to profile a typical entrepreneur (Boshoff, Bennett and Owusu, 1992; Stanworth, 1995). The third approach, which focuses on attitudes, is behaviour-specific rather than characteristic-specific (Robinson et al., 1991).

South African studies on demographic variables found significant differences between entrepreneurs and non-entrepreneurs in terms of language, age, place of birth, gender, marital status, race, educational level, religious affiliation and father's occupation (Boshoff \& Van Vuuren, 1993; Van Vuuren \& Boshoff, 1993). This view is confirmed by Schutte, Bennett and Boshoff (1993), who studied entrepreneurial ventures in a third world setting and found that demographic variables by themselves are moderate predictors of entrepreneurial success. 


\subsection{The measurement of traits}

Although recognised theorists in the field of psychology, such as Carl Rogers, Gordon Allport, Erik Erikson, George Kelly and Sigmund Freud (Hjelle \& Ziegler, 1986: 6-7), all propose their own definitions of personality, most definitions share a number of features:

- Personality is an abstraction based on inferences derived from behavioural observation.

- Personality reflects the special properties or combination of properties that distinguish one person from another.

- Personality is subject to a variety of internal and external influences, including genetic and biological propensities, social experiences, and changing environmental circumstances.

Aside from these common themes, personality definitions differ substantially and the definitions depend on the theory of personality chosen (Hjelle \& Ziegler, 1986).

Many personality theories, for instance Allport's (1961: 334), are based on surface traits. Often the selection of these traits is strongly influenced by the subjective preferences of the theorist. However, Raymond Cattell's 1940 s choice of 16 "source traits" for the 16PF depends on refined and variable statistical techniques which include mathematical models to describe and assess extensive data bases (Stephenson, 1952: 206). Cattell was a trait theorist who used Multiple Abstract Variance Analysis (MAVA) to identify clusters of "surface traits", consistent behavioural responses, and "temperament and ability source traits" which are the underlying variables that determine "surface traits" (Conn \& Rieke, 1994: 2).

Maas (1989: 11-14) asserts that Cattell considered it to be unscientific to formulate a complete definition of personality, because Cattell argued that the precise terms of agreed and rich significance do not yet exist. At best, Cattell was prepared to say that personality is "that which permits a prediction of what a person will do in a given situation". He also advocated that personality be viewed as a holistic and organic entity, but that due consideration be given to the role of source traits in assessing personality. In terms of his definition, source traits are the few unique underlying variables, which influence the manifestation of many surface traits or clusters of observable behavioural events.

According to Prinsloo (1991: 1-2), Cattell applied the technique of factor analysis to a list of 18000 words (eompiled by Allport \& Odbert in 1963) that 
comprehensively describe human behaviour to obtain a set of sixteen primary or first-stratum factors that he accepted as complete and accurate descriptions of personality traits. These 16 factors were seen as a summary of core personality traits, which are universal and stable across all nationalities. Cattell used mathematical techniques on a large pool of possible personality descriptions, and asserted that the $16 \mathrm{PF}$ is capable of measuring the true personality constructs present in people in a way that is both reliable and valid.

The 16 PF scales measure a person's characteristic style of thinking, perceiving and acting in a wide range of different situations and over a relatively long period. Each personality trait is manifested as a set of attitudes, preferences, habits, social and emotional reactions, and is derived from a complicated interaction between inherited disposition and leaming from experience. Some traits primarily involve internal regulation of defensive or adaptive impulses, while others are maintained as functionally autonomous habits or stylistic responses to the pressures of inner drives. These traits govern practically every facet of a person's overall functioning in the world (Cattell, 1989:2).

\subsection{The measurement of emotive responses to the environment}

The stated origins of the Thomas Personal Profile Analysis lie in Marston's biosocial theory, first formulated during the 1920s, which identified the uniqueness of each person as those feelings and purposeful actions that enable the person to modify and control the effects of the environment. The "painpleasure" principle implies that humans evaluate the environment along a continuum - antagonistic at one extreme, and favourable at the other. Perceptions of the hostile or favourable nature of the environment normally produce what Marston terms "vitalistic forces" or emotions: people try to "avoid pain" in antagonistic environments or "maximise pleasure" in favourable environments. Individuals develop a preferred or habitual tendency to confront changes in the environment by emotions that lead to active or passive behaviours. Emotions are experienced as part of the total response to the changes (Irvine, 1988a).

The advent of cross-cultural psychology during the 1960 s provided the basis for a more robust calibre of research which defined ecological frameworks for the acquisition of cognitive and social skills. Most cross-cultural psychologists (for a convenient overview see Irvine and Berry, 1983, 1988; Berry and Irvine, 1986) unwittingly support Marston's biosocial proposition that people and the physical and social environment modify each other through constant interaction. Ferguson $(1954,1956)$ was the first cross-cultural psychologist to formulate an ecological theory of human development that proposes that groups and their tendencies to thought and action are differentiated by environmental pressures. 
Ferguson's Law states that society determines what will be valued for survival in response to different environments and individuals within that society, then people learn patterns of thought and feeling as a natural consequence of these leamed values (Irvine \& Berry, 1988).

Irvine (1988a: 25 ) asserts that the most relevant contributions to understanding Marston's notion of adaptation to holistic and favourable work climates were made by Berry $(1976,1986)$, who expounded the central idea of "cognitive style" to account for habitual forms of problem-solving and social behaviour used to accommodate the work demands of contrasting environments. Berry asserts that some environments are intrinsically antagonistic to survival, in contrast to others which are favourable. Consequently, analytical habits of thought, independence and self-reliance are fostered in antagonistic environments, while less analytical modes of perception and thinking, social cohesion and compliance with social rules are encouraged by favourable environments.

Various modern biosocial approaches to personality confirm Marston's notion that a person's self-concept develops from habitual modification of actions sanctioned by others in the interaction between ecological pressures and dispositional tendencies. According to Geier (1979), an early technical manual (the PPA technical manual by Thomas Hendrickson, undated) asserts that the PPA has a generic resemblance to Jung's notion of psychological types and that its initial mode of construction is directly linked to trait psychology, particularly Allport's study of trait names.

References to Allport's work in published material on the PPA are so positive and so pervasive that it is necessary to clarify the nature of his ideas and their contribution to the construction of the PPA. Allport defined personality, much as Marston did, as an intemal, dynamically organised and adaptive response to the environment, which he described as consisting of the external world as well as of an individual's internal understanding of events to create meaning. $\mathrm{He}$ emphasised that the fusion in the individual of mental and physiological events produces characteristic modes of thought, feeling and action which exhibit themselves as definable and measurable entities or traits (Allport, 1961).

Allport preferred to seek explanations for motives in contemporary situations and feelings rather than in the surfacing of unconscious needs. In this, Allport supports Marston's concern with normality and consciousness as the mainsprings of human action. It follows that any immediate response to a structured set of stimuli, such as the adjectives that are used as trait descriptions in the PPA, provide insight primarily into the here-and-now responses of the individual in relation to the person's current environmental context. According 
to Irvine (1988b: 28), the originators of the PPA used Allport's unparalleled study of how people actually describe the personality characteristics or traits of others to confirm the four dimensions that are described by Marston and that form the basic construct of the PPA.

Marston's thinking is further confirmed by Horney (referred to by Krech, Crutchfield and Ballachey, 1962: 105). Horney argues that people resolve conflicts by taking actions that could be consistently classified. Conflict and accompanying stress are actively resolved by moving against others (aggression and dominance), by moving toward them (compliance), or by moving away from them (detachment).

Marston postulated four basic adoptive emotional conditions that are used directly as survival strategies from the interaction of antagonistic/favourable environments with the active/passive dispositional reactions of individuals (Irvine, 1988a: xx-xxi). Marston reasoned that an active reaction in an antagonistic environment would foster qualities of dominance, designed to oppose painful consequences and overcome obstacles by forceful personal actions. At the opposite pole, people with a positive disposition would try to reduce the painful effects of the hostile environment by responding with unwilling but cautious and calculated csompliance. In a favourable environment, an active emotive response would foster a person's attempt at influencing events through persuasion rather than at achieving dominance through confrontation. On the other hand, a habitual passive response in favourable situations would lead to easygoing acceptance of routine and produce Steadiness.

\subsection{The measurement of attitudes}

Lau (1992) asserts that trait and demographic approaches have reached their limit and are inappropriate as predictors of entrepreneurial behaviour, given the dynamic nature of entrepreneurship. Epstein (1984) observed that the trait approach is the most common theoretical and methodological approach used in researching the characteristics of people, but tends to measure general characteristics and is intended for use across a broad spectrum. The main criticism against the trait approach is that its research methodologies are based on personality theory, which was not developed for measuring entrepreneurship, and therefore use information that is not directly applicable (Carsrud \& Johnson, 1989; Sexton, 1987).

Another general criticism of personality measurement instruments is that they do not focus on measuring a specific dimension of a considered concept in a specific context, and this in turn decreases the appropriateness and accuracy of 
such instruments (Robinson et al., 1991). The diffusion of the focus of a measurement instrument across situations also reduces its efficacy in any particular context, primarily due to the addition of error associated with all the situations in which the instrument may be used (Ajzen \& Fishbein, 1977). For example, the measurement of innovation in business cannot really be equated to creativity scales that include artistic qualities such as spatial representation or colour co-ordination (both concepts that do not relate to most business situations).

Attitude theory offers another alternative for developing an instrument which focuses on measuring a specific dimension of a considered concept in a specific context. Attitude is defined as a person's predisposition to respond in a favourable or unfavourable manner with regard to the object of the attitude, be it a specific person, place, thing, event, activity, mental concept, cognitive orientation, life style or even combinations of these categories (Ajzen, 1982; Shaver, 1987). Because attitudes also exist at the general and specific levels for many objects, attitude specificity needs to be matched by measurement specificity (Shaver, 1987: 152; Ajzen \& Fishbein, 1977). Matching attitude specificity with measurement specificity not only increases the accuracy of the measurement within the specified domain, but also increases the predictability of the instrument because of this increased accuracy (Robinson et al., 1991: 14).

Attitudes are usually considered less stable than personality traits, in that they change over time, and from situation to situation, through interactive processes with the environment. The rate at which attitudes change may of course vary, depending both on how deep-seated or fundamental the attitude is to the individual's identity and on the intensity of the experiences that influence a particular attitude. This changeability in tum influences the consistency with which behaviours can be predicted from measured attitudes, particularly when attitudes are measured in very general ways (Chaiken \& Stanger, 1987).

Robinson, Stimpson, Huefner and Hunt (1991) attempted to avoid the abovementioned pitfalls in the development of the Entrepreneurial Attitude Questionnaire which measures an interrelated set of attitudes towards entrepreneurship across four constructs. Each of the subscales of the questionnaire consists of three components: cognitive (the person's beliefs about and thoughts towards the attitude object); affective (the person's beliefs and thoughts about the object); conative or behavioural (behavioural intentions to behave in a specific way toward the object). The four subscales measure achievement in business, innovation in business, perceived personal control of business outcomes and perceived self-esteem in business. 
Although Boshoff and Scholtz (1995) concur that the approach developed by Robinson, et al. (1991) must be seen as potentially very useful and consider it to be a major step forward in research in the entrepreneurial field, they conclude that entrepreneurs are not a homogeneous group and that it may be useful to differentiate between types of entrepreneurs.

\section{METHOD}

\subsection{Research design}

One of the most difficult aspects in ex post facto field studies is identifying adequate criteria for what represents success. For a criterion to be valid, it should of course measure important aspects of performance and the criterion measurements themselves should be reliable and valid. Once the criteria have been selected, the next problem is to secure dependable measurements, which are then combined and weighted (Guiford \& Fruchter, 1978). In the study discussed in this article, the scales of the 16 Personality Factor Questionnaire (16 PF), the Personal Profile Analysis, and the Entrepreneurial Attitude Questionnaire serve as the independent variables and three performance measures (restaurant evaluation, customer satisfaction evaluation and sales growth) were initially used as the dependent criteria variables. Later, sales growth was excluded as a variable.

\subsection{Sample description}

The target population consisted of the male and female franchisees who manage the fast food restaurants of an established South African franchise operation. Franchisees are the owners of the restaurants in terms of the franchise agreement. The sample consisted of approximately 200 restaurants which are geographically dispersed throughout all nine provinces of South Africa. In order to maximise the sample size, it was decided to include the total target population in the study. The sample group was selected at random.

The $16 \mathrm{PF}$, Personal Profile Analysis and Entrepreneurial Attitude Questionnaire were completed by 80 franchisees. This constitutes a response rate of 40 per cent. The sample consisted of 75 Whites, 3 Asians and 2 Blacks, and was made up of 64 males and 16 females, of which 37 were Englishspeaking and 43 Afrikaans-speaking. The minimum educational level of the sample group was Standard 10.

Respondents' experience in a franchise outlet ranged from 1 to 24 years, with an average of 8.19 years. It was found that 22.5 per cent of the respondents have 1 
or 2 years experience, 20 per cent have between 3 and 5 years experience, 22.5 per cent have 6 to 10 years experience, and 35 per cent have 11 to 25 years experience.

\subsection{Measuring instruments}

\subsubsection{The I6 Personality Factor Questionnaire}

The 16PF was developed by Cattell (Cattell et al., 1970) to measure 16 primary source traits. The instrument is generally used for counseling, guidance and selection purposes. Since its inception in 1949, the 16PF has become widely recognised as one of the most respected psychometric instruments to measure personality traits. Many studies have been conducted to examine the theoretical constructs of the I6PF, to validate its source traits, to evaluate its reliability and validity, and to research its application in various domains (see Spangenberg, 1990). Split-half reliability coefficients vary between 0.71 and 0.93 and are described as highly satisfactory (Cattell et al., 1970). Test-retest reliabilities vary between 0.74 and 0.90 and are also described as highly satisfactory (Prinsloo, 1995). The variables of the 16PF are measured on factor-analytical grounds, which means that face validity is not required (Smit, 1991).

The sixteen first-order source traits are described as follows:

- Factor A: Reserved vs. Warmhearted

- Factor B: Concrete-thinking vs. Abstract-thinking

- Factor C: Unstable vs. Stable

- Factor E: Submissive vs. Dominant

- Factor F: Desurgent vs. Surgent

- Factor G: Low superego strength vs. Superego strength

- Factor H: Restrained vs. Adventurous

- Factor l: Tough-minded vs Tender-minded

- Factor L: Trusting vs. Suspicious

- Factor M: Practical vs. Imaginitive

- Factor N: Naïvite vs. Shrewdness

- Factor 0: Self-assured vs. Apprehensive

- Factor Q1: Conservatism vs. Radicalism

- Factor Q2: Group-dependent vs. Self-sufficient

- Factor Q3: Uncontrolled vs. Controlled

- Factor Q4: Relaxed vs. Tense

The SA-92 Form as adapted by the Human Sciences Research Council was used, as it is considered culturally fair for South African conditions. 


\subsubsection{The Personal Profile Analysis}

Thomas International conducted various in-house studies to determine what the PPA actually measures in alternate psychological terms. The PPA was compared with recognised psychometric instruments which are considered to measure similar psychological properties. All these instruments have been demonstrated to possess sound predictive and construct validity. A comparison between the PPA, Cattell's I6PF and Saville and Holdsworth's Occupational Personality Questionnaire $(N=263)$ yielded correlations that ranged from 0.30 to 0.64 between the four dimensions of the PPA, the sixteen primary factors of the $16 \mathrm{PF}$ and the fifteen dimensions of the OPQ (Irvine, 1988b).

Kaplan (1982) conducted a comparative study between the PPA and the Wechsler Adult Intelligence Scale (WAIS), the Myers-Briggs Type Indicator (MBTI), Cattell's $16 \mathrm{PF}$, the Minnesota Multiphasic Personality Inventory (MMPI) and the Strong-Campbell Interest Inventory (SOII). The study yielded significant correlations exceeding the 5 per cent level of expectation:

- The similarities between the PPA and the MBTI were twelve times more significant than expected.

- The similarities between the PPA and the 16PF were over eight times the significance expected by chance alone.

- The PPA and SCII similarities were shown to be over four times chance expectancy.

- The PPA, WAIS and MMPI similarities were shown to be over four times chance expectancy.

The abovementioned results show that the PPA reflects similar personality dynamics and preferences to those revealed by the MBTI, 16PF, SCll and MMPI. The internal consistency of each (of the four) scales ranges between 0.60 and 0.74 . Test-retest reliabilities vary between 0.52 and 0.78 and are described as extremely high.

The PPA is used in 39 culturally different countries and to date no bias has been found with regard to its results in respect of culture, race or gender. Research conducted in South Africa on PPA profiles assessed since $1995(\mathrm{~N}=4240)$ also indicated no material bias against people from previously disadvantaged groups (Van Deventer, 1997; Van Deventer \& Kruger, 1997).

The most recent PPA Manual (undated) describes the PPA scales as follows:

- Dominance - drive to accomplishment in the face of opposition.

- Influence - influencing others to react favourably. 
- Steadiness - suitable for performing routine and repetitive work.

- Compliance - complying with high work standards to avoid trouble or error.

The PPA-Plus format was used in this study, as it has been refined to be appropriate for use by the diverse South African working population.

\subsubsection{The Entrepreneurial Attitude Questionnaire}

The Entrepreneurial Attitude Questionnaire (EAQ) developed by Robinson et al. (1991) is based on attitude theory as an alternative approach to personalitybased psychological models. Gasse (1985) confirmed this approach and contended that interrelated attitudes form a comprehensive and orderly pattern which can be taken as an indication of the degree of unity in an individual's orientation toward the object of the attitude. The EAQ differentiates between successful and unsuccessful entrepreneurs on the basis of attitudinal orientation.

In an empirical study conducted by Robinson et al. (1991), the scores of entrepreneurs and non-entrepreneurs were compared and significant differences were tested by means of a MANOVA. The analysis yielded a significant overall difference between entrepreneurs and non-entrepreneurs on all four subscales of the EAQ at the 0.001 level of probability. Univariate tests showed a highly significant difference between the entrepreneur and non-entrepreneur groups: the mean for the entrepreneur group was higher than that of the nonentrepreneur group on every subscale. The predictive validity of the four subscales was tested by means of a stepwise discriminant analysis using WilksLambda to predict membership of the entrepreneur and non-entrepreneur groups on the basis of the four subscales. Three of the four subscales contributed significantly to the discriminant function, with the exception of Achievement, which did not contribute significantly. Using classification function coefficients, group membership could be predicted with an accuracy ratio of 77 per cent. Test-retest reliabilities achieved for the attitudinal subscales were Innovation 0.85; Achievement 0.84; Personal Control 0.71; and self-esteem 0.76. Alpha coefficients were regarded as satisfactory at Innovation 0.90; Achievement 0.84; Personal Control 0.70; and Self-esteem 0.73 (Robinson et al, 1991).

An empirical study conducted by Scholtz (1993) to compare entrepreneurs, engineers and managers $(N=299)$ tested the validity and reliability of the EAQ scale under South African conditions and concluded that it is not culture free. Consequently, Boshoff, Scholtz, Jacobs and Stimpson (1993) revised the EAQ for South African conditions. They eliminated all items that obtained corrected $r$ tt values $<0.30$ in the Scholtz study from the questionnaire and they also adjusted the structure of the subscales. 
The EAQ consists of the following four subscales:

- Achievement in business, referring to concrete results associated with the start-up and growth of a business venture.

- Innovation in business, relating to perceiving and acting upon business activities in new and unique ways.

- Perceived personal control of business outcomes, conceming the individual's perception of control and influence over his or her business.

- Perceived self-esteem in business, pertaining to the self-confidence and perceived competence of an individual related to his or her business affairs.

The EAQ as revised by Boshoff for South African entrepreneurs in the manufacturing and non-manufacturing industries was used in this study.

\subsection{Performance criteria}

In terms of the criterion variable franchisee performance or effectiveness, it is noted that performance measures in the franchise sector are generally welldefined and consistently monitored in terms of the franchise agreement. Profitability, which includes assessing the gross and net profit of franchisees, was monitored by 92.3 per cent of the franchisors that participated in the 1998/1999 Annual Survey of the South African Franchise Sector (Franchize Directions, 1999). Franchisors also regularly monitor whether franchise outlets trade under the established trademark and operate according to the operations manual, which sets out the defined business method. Franchisors in the fast foods category often monitor profitability by means of sales growth and conduct restaurant evaluations to monitor whether franchisees operate according to the operations manual. They also regularly evaluate customer satisfaction. Franchise and therefore franchisee performance in this study was measured using two of the three performance indicators suggested (and used) by the franchisor, namely:

- Restaurant evaluation, which is conducted by the franchisor's Franchise Support Managers on at least three occasions per year. This evaluation assesses the achievement of franchise standards in terms of hygiene, maintenance, product management, service, hospitality, uniforms, management and marketing, and is essentially designed to assess the implementation of the franchisor's organisational delivery and control system.

- A customer satisfaction evaluation, which assesses hospitality, speed of service, restaurant ambience and management support from the customer's point of view. This so-called "mystery shopper" evaluation 
was designed to measure customer response to the particular products and services offered by the delivery and control system and is conducted by an anonymous visitor to the restaurant on at least six occasions per year.

Sales growth, which measures the annual growth of net sales per restaurant, was excluded from the performance criteria because it is strongly influenced by factors under the direct control of the franchisor. Consequently, percentage growth may not be directly attributable to actions taken by the franchisee and is therefore not a true assessment of success. Factors outside the franchisee's control include the strength of the trademark or brand, the location (site) and construction of the restaurant, the national distribution of equipment and raw materials, effective marketing and management of the franchise. However, sales growth is contingent on the maintenance of high restaurant and customer standards, which is directly under the control of the franchisee.

\subsection{Procedure}

The questionnaires were individually administered to 80 franchisees in an office environment during visits to franchise outlets. The franchisees were given the option to participate or not. Franchisee performance as measured by the identified (two) performance measures was assessed by the franchisor over a period of one year for each restaurant.

\subsection{Statistical analyses}

Franchisees were firstly classified into two groupings according to set performance criteria, namely successful or unsuccessful franchisees. Secondly, these two groups were then explored by means of a stepwise discriminant analysis based on linear combinations of the predictor variables (personality traits, emotive responses and attitudinal orientation) to provide the best overall discrimination among the groups. Next, the factors common to successful franchisees were identified. Lastly, the Jack-Knife Classification (Nell, Kamfer, Van der Merwe \& Venter, 1996) was employed to devise a classification table in order to compare the observed and predicted success rates of franchisees.

\section{RESULTS}

\subsection{Classification of Performance Criteria}

A simple dichotomy was formulated to include the performance criteria for statistical purposes. Franchisees were classified into two groups from average 
scores obtained on the Restaurant Evaluation and Mystery Shopper Reports over the period of one year. The arbitrary averages laid down by the franchisor to separate successful and unsuccessful franchisees were used as cut-off point for Restaurant Evaluation (91) and Mystery Shopper (83) scores. Consequently, 45 respondents were classified as successful and 35 respondents were classified as unsuccessful. Table 2 sets out a description of the two groups.

Table 2 Description of the sample in terms of performance criteria

\begin{tabular}{|l|c|c|c|c|}
\hline \multicolumn{1}{|c|}{ Group } & $\begin{array}{c}\text { Restaurant } \\
\text { evaluation }\end{array}$ & $\begin{array}{c}\text { Mystery } \\
\text { shopper }\end{array}$ & $\begin{array}{c}\text { Group } \\
\text { size }\end{array}$ & $\begin{array}{c}\text { \% of total } \\
\text { group }\end{array}$ \\
\hline Successful franchisees & 91 to $100 \%$ & 83 to $100 \%$ & 45 & $56 \%$ \\
\hline $\begin{array}{l}\text { Unsuccessful } \\
\text { franchisees }\end{array}$ & 0 to $90 \%$ & 0 to $82 \%$ & 35 & $44 \%$ \\
\hline Total & - & - & 80 & $100 \%$ \\
\hline
\end{tabular}

The Jack-Knife Classification was used as a method to ascertain whether the two groups were correctly classified in terms of the performance criteria. The classification results are reflected in Table 3. From Table 3 it is clear that 44 of the successful franchisees were correctly classified, while 1 of the successful franchisees was incorrectly classified. Of the unsuccessful franchisees, 34 were correctly classified and 1 was incorrectly classified. This implies that 97.5 per cent of grouped cases were correctly classified and only 2.5 per cent were incorrectly classified.

Table 3 Predicted group membership in terms of performance criteria

\begin{tabular}{|l|c|c|c|}
\hline \multicolumn{1}{|c|}{ Franchisees } & $\begin{array}{c}\text { Number of } \\
\text { cases }\end{array}$ & \multicolumn{2}{|c|}{ Predicted membership } \\
\hline & & Successful & Unsuccessful \\
\hline Successful & 45 & $44(97.8 \%)$ & $1(2.2 \%)$ \\
\hline Unsuccessful & 35 & $1(2.9 \%)$ & $34(97.1 \%)$ \\
\hline
\end{tabular}

\subsection{Discriminant analysis of personality attributes}

The difference between the successful / unsuccessful franchisees (dependent variable) was further explored by means of a stepwise discriminant analysis (Morgan \& Griego, 1997: 154) using a variety of recognised statistical methods, including the Wilks-Lambda, Canonical Discriminant Function, Structured Matrix, and Fisher's Linear Discrimination. The independent (predictor) variables consisted of the sixteen factors of the 16PF, four factors of the PPA, 
and four factors of the EAQ. The analyses showed that three factors of the 16PF, one factor of the PPA, one factor of the EAQ varied significantly between the groups. The results of the Fisher's Linear Discrimination, which is most appropriate for small groups ( 80 is considered a small sample for statistical purposes), is set out in Table 4. The table reflects the weights for the linear combination of variables that discriminate most between successful and unsuccessful franchisees.

Table 4 Diseriminant function coefficients of the predictors

\begin{tabular}{|l|c|c|}
\hline Predictors & Successful & Unsuccessful \\
\hline & Coefficients & Coefficients \\
\hline Emotional Stability (Factor C - 16PF) & 0.886629 & 0.728138 \\
Caution (Factor F - 16PF) & 1.644076 & 1.844949 \\
Shrewdness (Factor N - 16PF) & 3.897153 & 3.543380 \\
Compliance (PPA) & 2.961377 & 2.788327 \\
Self-Esteem (EAQ) & 2.821686 & 2.653440 \\
\hline Constants & -112.7659 & -101.3134 \\
\hline
\end{tabular}

The results in Table 4 indicate that Emotional Stability, Caution and Shrewdness (all 16PF); and then also Compliance (PPA) and Self-Esteem (EAQ) are the predictor variables which provide the best discrimination between successful and unsuccessful franchisees.

The Jack-Knife Classification was again used to check the effectiveness of the discriminant analysis. The weights of the five predictors (personality attributes), as identified during the stepwise discriminant analysis, were used to predict group membership of the franchisees. The results are reflected in Table 5.

Table 5 Predicted group membership in terms of personality attributes

\begin{tabular}{|l|c|c|c|}
\hline \multicolumn{1}{|c|}{ Franchisees } & $\begin{array}{c}\text { Number of } \\
\text { cases }\end{array}$ & \multicolumn{2}{|c|}{ Predicted membership } \\
\hline & & Successful & Unsuccessful \\
\hline Successful & 45 & $31(68.9 \%)$ & $14(31.1 \%)$ \\
\hline Unsuccessful & 35 & $10(28.1 \%)$ & $25(71.4 \%)$ \\
\hline
\end{tabular}

The use of Emotional Stability, Caution, Shrewdness, Compliance and SelfEsteem as predictors of performance resulted in the correct prediction of 68.9 per cent of the successful group and 71.4 per cent of the unsuccessful group. Overall, 70.15 per cent of the respondents were correctly classified into the 
appropriate performance groups. The discriminant analysis, however, did better in predicting who would be unsuccessful than it did at predicting who would be successful.

\section{DISCUSSION}

The empirical study showed that the personality attributes of successful franchisees differ significantly from those of unsuccessful franchisees with regard to Emotional Stability, Caution, Shrewdness, Compliance and SelfEsteem. Successful franchisees exercise a higher degree of emotional discipline and display more caution and restraint than unsuccessful franchisees. They also pay significantly greater attention to detail and follow a more calculating and factual approach towards work methods. They display a higher degree of interpersonal insight and also come across as significantly more self-assured and competent.

The accuracy ratio of 70.15 per cent in correctly classifying successful and unsuccessful franchisees on the basis of the identified five factors provides a sound basis for the formulation of two equations which can be used to screen potential franchisees in the fast foods category. The prediction formulae can be derived from the results set out in Table 4 . The prediction formula for successful franchisees is expressed as $\mathrm{S1}$ and the prediction formula for unsuccessful franchisees is expressed as U1.

$\mathrm{Sl}=2.8217 \mathrm{EQ} 4+1.6441 \quad \mathrm{PF} 5+3.8972$ PF1 $1+2.9614$ PA4+0.8866 PF3112.7659

$\mathrm{Ul}=2.6534 \quad \mathrm{EQ} 4+1.8449 \quad \mathrm{PF} 5+3.5434$ PF11+2.7883 PA4+0.7281 PF3101.3134

These two formulae can be used to differentiate between successful and unsuccessful candidates by entering the scores obtained for the five factors into both formulae for each candidate. This means that two scores are computed for each candidate on S1 and U1 respectively. The greater of these two scores will predict with a 70 per cent accuracy rate whether a candidate has the potential to become a successful or unsuccessful franchisee.

Of course, these two formulae can only be used once candidates have completed the 16PF, the EAQ and the PPA. Combined, these three questionnaires measure 24 traits / responses / attitudes, comprising 331 items and take approximately 100 minutes to complete. Marking and interpretation of each questionnaire can be done manually, or by means of software packages in the case of the 16PF 
and PPA. Marking and interpreting the questionnaires and computing the formulae, S1 and U1 takes at least 20 minutes, adding up to a total test time of 120 minutes per candidate.

A better altemative would be to identify or construct a questionnaire based on the five factors identified from the research. Such a questionnaire should consist of no more than 80 items, it should take approximately 15 minutes to complete and it should be possible to score it in about 10 minutes, which would reduce the total test time when using the $16 \mathrm{PF}$, the PPA and the EAQ from approximately 100 minutes to 25 minutes. The questionnaire should also not require sophisticated scoring techniques, but must be designed to be scored either by hand or computer.

The research results provide a sound foundation for the identification or construction of a questionnaire that reflects the intrinsic nature of the five factors identified from the $16 \mathrm{PF}$, the EAQ and the PPA. Once such a questionnaire has been identified or constructed, it should be validated by administering it to a representative group of franchisees in the fast foods sector and their questionnaire results should then be correlated with appropriate performance criteria. It is likely that factor analysis of how franchisees answer each question of the newly constructed questionnaire would enable further refinement to increase the questionnaire's accuracy ratio to above 70 per cent.

\section{6 MANAGERIAL IMPLICATIONS}

This study has highlighted that successful franchisees appear to display behaviours that reduce risk - for example, they exercise emotional discipline, caution and restraint, pay greater attention to detail and follow a calculating and factual approach towards work methods. Indeed, this finding is not surprising, as the franchise concept is essentially an attempt to reduce the amount of risktaking in setting up, establishing, managing and growing a new business. The results of the present study strongly suggest that franchisees may differ from entrepreneurs in meaningful ways and operate in different contexts. The underlying culture and values conducive to success in a risk-minimised and highly structured business context (the franchise concept) may be quite inappropriate in an entrepreneur's operating context, which is characterised by an increase in risk and less structure. The findings offer support for the view that franchisees are not truly entrepreneurial in nature but instead behave more like intrapreneurs, who want to own and develop their own businesses, but prefer to keep to proven conventional products and services (Kao, 1991). This suggests several potentially useful avenues for continued research. 
The relationships between the three main performance criteria used by the franchisor to determine franchisee effectiveness and success also warrant further investigation. According to the franchisor, the maintenance of franchise standards (as assessed by the restaurant evaluation) forms the basis for the achievement of sound customer service (as assessed by the Mystery Shopper evaluation). The improvement and maintenance of franchise standards and sound customer service are directly under the direct control of the franchisee. However, it appears that sales growth (which determines the ultimate success of the restaurant) may not be under the direct control of the franchisee, as the franchisor controls many of the factors that influence sales growth, for example, the strength of the trademark or brand, the location (site) and construction of the restaurant, the national distribution of equipment and raw materials, effective marketing and management of the franchise. First, the relationship between restaurant standards and customer satisfaction should be carefully explored to confirm whether the maintenance of franchise (restaurant) standards serve as a basis for customer satisfaction. Second, the relationship between restaurant standards and customer satisfaction on the one hand, and financial profits on the other hand should be investigated to isolate the factors in the franchise concept that should be under the franchisor's control (in order to maintain the integrity and standards of the franchise) and those factors that should be under the franchisee's control in order to ensure continued growth in the effectiveness and earnings of the franchise.

It is also notable that the franchisor generally rates franchisee performance (restaurant evaluation) higher than independent outsiders (customer satisfaction evaluation) do. Indeed, a major limitation of the study is the skewness of both the restaurant evaluation and the customer satisfaction evaluation distributions (restaurant evaluation cut-off value: 91 and customer satisfaction evaluation cutoff value: 83 with an upper limit of 100 in both cases. This may mean that the method and frequency of performance assessments need to be re-considered, with a greater emphasis on uniform and consistent training and performance assessments.

\section{ENDNOTE}

This article is based on papers delivered at the Ninth European Congress on Work and Organizational Psychology, 12-15 May 1999, Espoo - Helsinki, Finland. 


\section{REFERENCES}

1 ABELL, M. (1992) The Franchise Option, London: Waterlow.

2 AJZEN, I. (1982) "On Behaving in Accordance with One's Attitudes", In M.P. Zanna, E.T. Higgins \& C.P. Herman (eds.) Consistency in Social Behaviour: The Ontario symposium, (2): 3-15. Hillsdale, NJ: Erlbaum.

3 AJZEN, I. \& FISHBEIN, M. (1977) "Attitude - Behaviour Relations: A Theoretical Analysis and Review of Empirical Research", Psychological Bulletin, 84: 888-918.

4 ALLPORT, G.W. (1961) Pattern and Growth in Personality, New York: Holt, Rhinehart.

5 BERRY, J.W. (1976) Human Ecology and Cognitive Style, New York: Sage-Halsted.

6 BERRY, J.W. (1986) On the Edge of the Forest: Cultural Adaptation and Cognitive Development in Central Africa, Lisse, Netherlands: Swets and Zeitlinger.

7 BERRY, J.W. \& IRVINE, S.H. (1986) Bricolage: Savages Do it Daily, In R.J. Sternberg and R.K. Wagner (eds.) Practical Intelligence, New York: Cambridge.

8 BOSHOFF, A.B., BENNETT, H.F. \& OWUSU, A.A. (1992) "Entrepreneurship Research: Where Are We and Where Should We be Going?" Development Southern Africa, 9(1): 47-64.

9 BOSHOFF, A.B. \& SCHOLTZ, C.P.T. (1995) Measuring Attitudes as a Way of Differentiating Entrepreneurs, Pretoria: University of Pretoria.

10 BOSHOFF, A.B., SCHOLTZ, C.P.T., JACOBS \& STIMPSON, D.V. (1993) "The Entrepreneurial Attitude Orientation Scale. Some South African Validation Results", Paper presented at International Entrepreneurial Conference, Vienna 4-7 July.

11 BOSHOFF, A.B. \& VAN VUUREN, J.J.J. (1993) "Towards Understanding the Entrepreneurial Personality - A South African Study", In H. Klandt \& D. Muller-Bohling (eds.) Internationalizing Entrepreneurship Education and Training, Cologne: Förderkreis GründungsForschung.

12 BROCKHAUS, R.H. \& HORWITZ, P.S. (1986) "The Psychology of the Entrepreneur", In D.L. Sexton \& R.W. Smilar (eds.) The Art and Science of Entrepreneurship, Cambridge MA: Ballinger.

13 CARSRUD, A.L. \& JOHNSON, R.W. (1989) "Entrepreneurship: A Social Psychological Perspective", Entrepreneurship and Regional Development: An Intemational Joumal, 1(1): 21-31.

14 CATTELL, H.B. (1989) The I6PF: Personality in Depth, Champaigne, Illinois: Institute for Personality and Ability Testing, Inc. 
15 CATTELL, R.B, EBER, H.W. \& TATSUOKA, M.M. (1970) Handbook for the Sixteen Personality Factor Questionnaire (16 PF), Champaigne, Illinois: Institute for Personality and Ability Testing, Inc:

16 CHAIKEN, S. \& STANGER, C. (1987) "Attitudes and Attitude Change", Annual Review of Psychology, 38: 575-630.

17 CONN, S.R. \& RIEKE, M.L. (1994) The I6PF Fifth Edition Technical Manual, Champaigne, Illinois: Institute for Personality and Ability Testing lnc.

18 EPSTEN, S. (1984) "A Procedural Note on the Measurement of Broad Dispositions", Joumal of Personality, 52: 318-25.

19 FERGUSON, G.A. (1954) "On Learning and Human Ability", Canadian Journal of Psychology, 8: 95-112.

20 FERGUSON, G.A. (1956) "On Transfer and the Abilities of Man", Canadian Journal of Psychology, 10: 121-31.

21 FRANCHIZE DIRECTIONS. (1999) "Franchise Factor: 1998/1999", Third Annual Survey of the Franchise Sector. Rivonia.

22 GARTNER, W.B. (1988) "Who is an Entrepreneur? Is the Wrong Question", American Joumal of Small Business, Spring: 11-32.

23 GASSE, Y. (1985) "A Strategy for the Promotion and Identification of Potential Entrepreneurs at the Secondary School Level", In J.A. Hornaday, B. Shils, J.A. Timmons, \& K.H. Vesper (eds.), Frontiers of Entrepreneurship Research, Wessesley, MA: Babson College.

24 GEIER, J.G. (ed.) (1979) The Emotions of Normal People, by W.M. Marston, Minneapolis: Persona Press.

25 GORDON, B. (1999) Personal communication, November 2, 1999.

26 GUIFORD, J.P. \& FRUCHTER, J.P. (1978). Fundamental Statistics in Psychology and Education, Singapore: McGraw-Hill.

27 HARRIS, G.D. (1993) Franchising: $A$ Commercial and Legal Guide, London: Wragge and Co.

28 HISRICH, R.D. (1990) "Entrepreneurship/ Intrapreneurship", American Psychologist, 45 (2): 202-222.

29 HISRICH, R.D. \& BRUSH, C.G. (1986) The Woman Entrepreneur: Starting, Financing and Managing a Successful New Business, Lexington MA: Lexington Books.

30 HJELLE, L.A. \& ZIEGLER, D.J. (1986). Personality Theories. Johannesburg: McGraw-Hill.

31 IRVINE, S.H. (ed.) (1988a) Emotions of Normal People, by W.M. Marston, Ormskirk, Lancs: Thomas Lyster.

32 IRVINE, S.H. (1988b) Personal Profile Analysis: Technical Handbook. Ormskirk, Lancs: Leyland Printing.

33 IRVINE, S.H. \& BERRY, J.W. (eds.) (1983) Human Assessment and Cultural Factors, New York: Plenum. 
34 IRVINE, S.H. \& BERRY, J.W, (eds.) (1988) Human Abilities in Cultural Context, New York: Cambridge.

35 KAO, J.J. (1991) The Entrepreneur, Englewood Cliffs, NJ: Prentice Hall.

36 KAPLAN, S.J. (1982) The Kaplan Report, Chervy Chase, Maryland: Kaplan Associates.

37 KASSELMANN, B VON H. (1996) First Status Report of Franchise Selection Project, Sandton: Pleasure Foods.

38 KRECH, D., CRUTCHFIELD, R.S. \& BALLACHEY, E.L. (1962) Individual in Society, New York: Mc Graw Hill.

39 LAU, T. (1992) "The Incident Method - An Alternative Way of Studying Entrepreneurial Behaviour", In H. Klant, \& D. Muller-Bohling (eds.). Internationalizing Entrepreneurship Education and Training, Cologne: Förderkreis Gründungs-Forschung.

40 MAAS, F. (1989) Die Persoonlikheidsteorie van Cattell, Pretoria: Raad vir Geesteswetenskaplike Navorsing.

41 MACMILLAN, A. (1996) Aspects of Franchisee Recruitment, Westminister Press: International Franchise Research Centre.

42 MARSTON, W.M. (1989) Emotions of Normal People, Harcourt Brace: New York.

43 MENDELSOHN, M. (1994) How to Evaluate a Franchisee, Braamfontein: The Franchise Association of Southern Africa.

44 MORGAN, G.A. \& GRIEGO, O.V. (1998) Easy Use and Interpretation of SPSS for Windows: Answering Research Questions with Statistics. Lawrence Erlbaum Associates, London

45 NELL, T.L., KAMFER, L., VAN DER MERWE, R.P. \& VENTER, D.J.L. (1996) "Die Persoonlikheidsprofiel van Suksesvolle Bewakingspersoneel", Joumal of Industrial Psychology, 22 (3), 7-12.

46 NORUSIS, M.J. (1997) SPSS Professional Statistics 7.5. Chicago: SPSS Inc.

47 PINCHOT, G., III. (1985) Intrapreneurship, New York: Harper and Row.

48 PRINSLOO, C.F.I. (1991) Norms, Means, Standard Deviations and Reality Coefficients for the Sixteen Personality Factor Questionnaire (Form A), Pretoria: Human Sciences Research Council.

49 PRINSLOO, C.H. (1995) Manual for the Use of the Sixteen Personality Factor Questionnaire, South African Version (16PF, SA92), Pretoria: Human Sciences Research Council.

50 ROBINSON, P.B., STTMPSON, D.V., HUEFNER, J.C. \& HUNT, H.K. (1991) An Attitudinal Approach to the Prediction of Entrepreneurship, Entrepreneurship Theory and Practice, Summer: 13-31.

51 SCHOLTZ, C.P.T. (1993) "Houdings en Voorkeure as Metodes om te Onderskei tussen Entrepreneurs, Ingenieurs en Bestuurders: Suksesvolle en Minder Suksesvolle Entrepreneurs: en tussen Entrepreneurs in 
Verskillende Ekonomiese Sektore", Ongepubliseerde Doktorale proefskrif, Universiteit van Pretoria.

52 SCHUTTE, J.L., BENNETT, F. and BOSHOFF, A.B. (1993) "Prediction of Success Level of Entrepreneurial Ventures by means of Biographical and Business Variables in a Third World Setting", Proceedings of an International Congtess on Internationalizing Entrepreneurship Education and Training, Vienna: 381-95.

53 SEXTON, D.L. (1987) "Advancing Small Business Research: Utilizing Research from Other Areas", American Journal of Small Business, 11(3): 25-30.

54 SHAVER, K.G. (1987) Principles of Social Psychology, Cambridge, MA: Winthrop.

55 SMIT, G.J. (1991) Psigometrika, Pretoria: Haum.

56 SPANGENBERG, H. (1990) Assessing Managerial Competence, Cape Town: Juta.

57 STANWORTH, J. (1995) Developing a Diagnostic Questionnaire as an Aid to Franchisee Selection, Westminister Press: International Franchise Research Centre.

58 STEPHENSON, W. (1952) The Study of Behaviour, 0-technique and its Methodology Etc, Chicago Press.

59 THOMAS INTERNATIONAL. (Undated) Increasing People Effectiveness, Pretoria.

60 VAN DEVENTER, V. \& KRUGER, J. (1997) South African Data Supports Thomas System, Pretoria: Thomas International.

61 VAN DEVENTER, V. (1997) Thomas International on Thomas System Research, Pretoria: Thomas International.

62 VAN VUUREN, J.J.J. \& BOSHOFF, A.B. (1993) "Entrepreneurs! Are They Different? A Re-Analysis of a South African Data Set", Proceedings of an Intemational Congress on Internationalizing Entrepreneurship Education and Training, Vienna : 397-411. 